\title{
Moisture Stress and Different Rates of Nutrients on Growth and Yield of Rice
}

\author{
K P Halder ${ }^{1}$, M S Islam², M R Manir ${ }^{3}$ and M A Ali ${ }^{4}$
}

\begin{abstract}
The experiment was conducted at the Bangladesh Rice Research Institute (BRRI) Gazipur farm during Boro 2003-04 seasons to observe the moisture stress effects in relation to nutrient rates on growth and yield of rice. The treatments were three moisture stresses (NS= Always saturated condition i.e. 1-2 cm standing water; VPS= Withholding water at the vegetative phase i.e. 15 days after transplanting (DAT) to maximum tillering stage; RPS=Withholding water at the reproductive phase i.e. PI to flowering stage) and three fertilizer doses $(\mathrm{F} 0=$ No fertilizer; $\mathrm{HD}=$ Half of the optimum dose and $\mathrm{OD}=$ Optimum dose i.e. 120-60-40-10-2 $\mathrm{kg}^{-1}$ of $\mathrm{N}, \mathrm{P}_{2} \mathrm{O}_{5}, \mathrm{~K}_{2} \mathrm{O}, \mathrm{S}$ and $\mathrm{Zn}$ respectively). The treatments were applied in high yielding variety BRRI dhan29. The result showed that irrespective of nutrient rates, drought stress decreased plant height, tiller number and shoot dry weight. Unstressed plants (NS) produced the highest grain yield (3.14 to 6.51 tha $^{-1}$ ) followed by vegetative phase stressed (VPS) plants (2.73 to 4.50 tha $^{-1}$ ). The reproductive phase stressed (RPS) plants produced the lowest grain yield (2.54 to $\left.4.20 \mathrm{t} \mathrm{ha}^{-1}\right)$. Regardless of water stress, application of optimum dose (OD) of nutrients produced the highest grain yield followed by half dose (HD) of nutrients. No fertilizer treatment (F0) produced the lowest grain yield. Due to water stress, the highest grain yield reduction occurred in OD $(22-32 \%)$ followed by HD $(12-19 \%)$ and the lowest in F0 $(4-15 \%)$.
\end{abstract}

Key words: Rice (Oryza sativa L.), moisture stress, nutrients rates, plant growth, yield and yield components

\section{INTRODUCTION}

Rice is the most important food crop for more than half of the world population, especially in developing countries such as Asia, where water scarcity and drought are imminent threats to food security. Rice supplies more than $50 \%$ of calorie and $75 \%$ of protein consumed by the people of the developing countries (Khush, 2005). Its flexibility and adaptation to natural conditions, rice is planted in about 113 countries of the world (Rice is life, 2005). Drought is the most important limiting factor for crop production and it has been increasing day by day and becoming a severe problem in many regions of the world. Most of the crops are sensitive to drought stress particularly during flowering to grain filling stage (Sabetfar et al.,
2013). Rice uses two to five times more water than other cereal food crops such as wheat or maize and uses about $30 \%$ of the freshwater used for agricultural crops worldwide. Water stress is the most important limiting factor for growing rice. About 1,100 to 1,200 litres of water is required to produce $1.0 \mathrm{~kg}$ rough rice (Rice is life, 2005). Sometimes it may increase up to 4,000 litres. Exploring the ways to reduce water use for rice production is therefore of great strategic value for sustainable crop production for the world facing water scarcity (Molden et al., 2010). The plants anatomy, morphology, physiology and biochemistry as well as their growth and development also affected by drought stress (Heidary et al., 2007). Under a water stress situation, root growth is less inhibited than shoot growth and the dry matter partitioning between

1Director (Administration and Common Service), ${ }^{2}$ Principal Scientific Officer, ${ }^{3}$ Senior Scientific Officer, Farm Management Division, ${ }^{4}$ Former Director (Administration and Common Service), BRRI. *Corresponding author's E-mail: kphalder62@yahoo.com 
root and shoot was altered depending on moisture availability (Blum et al., 1983; Penning de Vries et al., 1989).

Keller (2005) reported that water and nutrients exist together in close association because plant available nutrient ions are dissolved in the soil solution and nutrient uptake by plant roots depends on water flow through the soil-root-shoot pathway. Leaf transpiration generates the tension necessary for the roots to absorb this essential solution, but in a dry soil, uptake of water and nutrients becomes progressively more difficult for any crop. Viets (1972) observed that nutrient and water absorption are independent processes in root, the necessity for available water in both the plant and soil for growth and nutrient transport makes them closely related. This close relationship makes it complex to clearly define the effects of water stress on mineral nutrition. Slatyer (1969) stated that the effect of water stress on mineral nutrition is difficult to resolve clearly. The key point is whether or not reduced nutrient uptake retards growth and development in a plant under stress. It results in an increase of solute concentration outside the roots compared to the internal environment of the root and causes reverse osmosis. As a result, the cell membrane shrinks from the cell wall and may eventually lead to death of the cell. Moisture stress inhibits photosynthesis in plants by closing stomata and damaging the chlorophyll contents and photosynthetic apparatus (Waraich et al., 2011).

Drought stress at vegetative phase of rice had minor effect on subsequent growth and grain yield. The reduction of grain yield was upto $30 \%$ due to decrease in panicle number in one trial and reduced spikelet number in another trial (Boonjung and Fukai,1996). They also reported that water stress at panicle development stage decreased grain yield due to delayed anthesis and the number of spikelets per panicle reduced upto $60 \%$ compared to control and the percentage of filled grains decreased upto to zero. The decrease in grain yield is associated with low dry matter production during the drought period as well as during the recovery period following the drought (Halder and Burrage, 2003). Drought stress at an early seedling stage may cause wilting, rolling, and drying of leaves (Murty and Ramakrishnayya, 1982). Water stress at the tillering stage reduces plant height, tiller number and leaf area. It induces leaf rolling, drying and premature leaf death and prolongs the vegetative stage (IRRI, 1976; Lee et al., 1994). The effects may occur even after stress has been eliminated (Jana and Ghildyal, 1972; O' Toole and Cruz, 1979). Cruz et al., (1986) found that mild water stress during vegetative growth decreased tiller and panicle number, leaf area, shoot and total dry matter mass. Castillo et al. (1987); BRRI (1991) reported that when water stress occurs during the vegetative phase, total dry matter production is decreased at harvest due to slow growth and the production of a smaller number of tillers.

Drought stress during the reproductive growth affects essentially all aspects of rice growth and development (Sharma et al., 1987; Okada, et al., 2002; Tuong et al., 2002). Depending on the severity and duration, early water deficit induces leaf rolling, drying, reduced photosynthetic activity, leaf water potential, plant height, leaf area, leaf number, dry matter yield, spikelet fertility, grain yield and delayed the onset of the reproductive growth period as well as delayed flowering and maturity (Yang et al., 1994; Tuong et al., 2002). When drought occurred during grain filling, the percentage of filled grains decreased to $40 \%$ and individual grain mass decreased by 20\% (Boonjung and Fukai, 1996). Water stress in rice plant decreases the rate of photosynthesis that affects the number of tiller, leaf area, dry matter accumulation, filled grain per panicle, 1000 grain weight and grain yield (Halder and Burrage 2004; Zumber et al., 2007; Sabetfar et. al., 2013). 
Information regarding the effect of moisture stress and different rates of nutrients on the growth, yield and yield components of rice is scanty. Therefore, this experiment was undertaken to investigate the effect of moisture stress and different doses of nutrients on the growth, yield and yield components of rice.

\section{MATERIALS AND METHODS}

The experiment was conducted at the BRRI farm Gazipur during Boro 2003-04 season. The treatments were three moisture stresses (NS= Always saturated condition i.e. $1-2 \mathrm{~cm}$ standing water; VPS= Withholding water at the vegetative phase i.e. 15 DAT to maximum tillering stage; RPS=Withholding water at the reproductive phase i.e. PI to flowering stage) and three fertilizer doses $(\mathrm{F} 0=$ No fertilizer; $\mathrm{HD}=$ Half of the optimum dose and $\mathrm{OD}=$ Optimum dose i.e. 120-60-40-10-2 kg ha-1 of N, $\mathrm{P}_{2} \mathrm{O}_{5}, \mathrm{~K}_{2} \mathrm{O}, \mathrm{S}$ and $\mathrm{Zn}$, respectively). The treatments were arranged in a randomized complete block design (Factorial) with three replications. BRRI dhan 29 was used as tested variety. The unit plot size was $4 \mathrm{~m} \times 4 \mathrm{~m}$. Thirty-five-day-old seedling @ 3 seedlings per hill was transplanted. The plant height, tiller number per hill and plant samples were collected from 15 days after transplanting (DAT) i.e. from stress imposed to maturity of the crop with 28 days intervals. The sampling days were $\mathrm{D} 1=0$ days after stress imposed (DASI), D2=28 DASI, D3=56 DASI, D4=84 DASI and D5 $=112$ DASI. At the maturity of the crop, the grain yield was recorded from $5-\mathrm{m}^{2}$ area excluding the border rows and weight was adjusted at $14 \%$ moisture content. The collected data were analyzed by following a standard statistical procedure and the mean differences were adjusted by LSD method.

\section{RESULTS AND DISCUSSION}

Plant height. Regardless of nutrient rates, water stress significantly $(\mathrm{P}<0.05)$ reduced plant height of vegetative phase stressed (VPS) plants (Fig. 1). At the end of the vegetative phase, when water stress was withdrawn from the VPS plants, there was a sharp increase of plant height but it could not reach reproductive phase stressed (RPS) plants. It was significantly $(\mathrm{P}<0.05)$ lower than the RPS plants. When water stress was imposed in the RPS plant, the plant height did not decrease significantly $(\mathrm{P}>0.05)$. The unstressed (NS) plants showed the highest plant height. IRRI (1976) reported that drought stress at vegetative and reproductive phase decreased plant height.

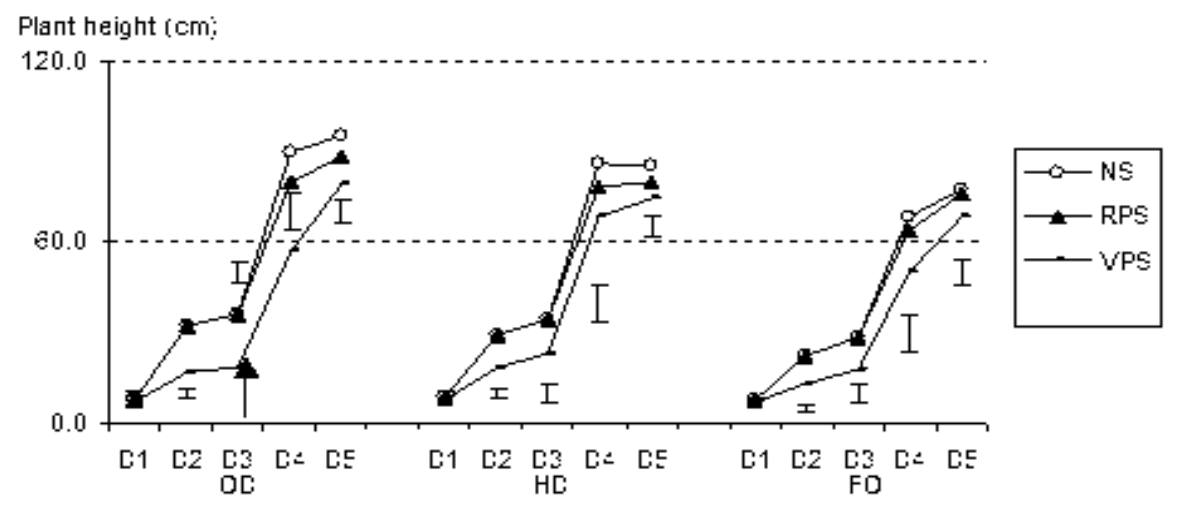

Fig. 1. Plant height as affected by nutrient rates and moisture stress throughout the experimental period. Arrow at D3 indicates the end of the VPS and start of RPS. (Vertical bars represent the LSD $(0.05)$ value indicates the difference among the water stress under same level of nutrient rates and among the nutrient rates under same level of water stress.) 
Tiller number. Regardless of nutrient rates, water stress significantly $(\mathrm{P}<0.05)$ reduced tiller number of vegetative phase stressed (VPS) plants (Fig. 2). Yoshida (1981) stated that in the vegetative phase, rice plants produced tillers from the leaf axils at each unelongated node. Due to some environmental limitations such as water and nutrient supply, light etc. tiller production may be inhibited and all the tiller buds do not develop into tillers. At the end of the vegetative phase, there was a sharp increase of tiller number of VPS, plants however, it was significantly $(\mathrm{P}<0.05)$ lower than the RPS plants of OD. In HD and F0 it was not significantly lower $(P>0.05)$ than OD. Yoshida (1981); Smith and Hamel (1991) observed that the tillering of rice depends on the nutritional status of the plant and tillering is highly impaired by a lack of $\mathrm{N}$ or P. The experiment here confirmed these findings; a larger number of tillers being produced by the plants grown in the higher nutrient i.e. OD. When water stress was imposed in the RPS plants, the tiller number did not decrease significantly $(\mathrm{P}>0.05)$. The unstressed (NS) plants had the highest tiller number. The tiller produced after vegetative phase was unproductive.

Shoot dry weight. Water stress significantly decreased the shoot dry weight under both vegetative phase and reproductive phases (Fig. 3). Dry weight increased after removal of water stress from vegetative phase stressed (VPS). However, it was lower than unstressed (NS) plants. Researchers reported that dry matter production decreased in water stressed plant also due to a reduction of cell turgidity, which affects cell expansion (Mengel and Kirkby, 1987; Hsiao, 1973) or alternatively might be due to both chemical and hydraulic signaling of the effects of soil drying (Davies $e t$ al., 2000).

Table 1 shows that the interaction effect of drought stress and nutrient rates was significant $(\mathrm{P}>0.05)$ in yield and yield components except 1000-grains weight.
Panicle number. Irrespective of moisture stress, the highest number of panicles was observed in OD followed by HD but there was no significant difference between HD and OD. The lowest number of panicles was found in F0. Regardless of nutrient rates the NS plants produced the highest number of panicles. The lowest number of panicles was found in RPS plant under F0 and in VPS plants under HD and OD but there was no significant difference between VPS and RPS. Hsiao (1982) stated that water stress enhance the poor flowering and incomplete panicle exertion.

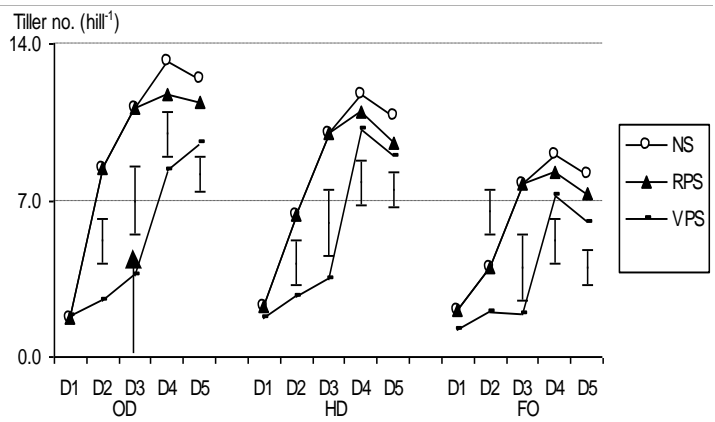

Fig. 2. Tiller number as affected by nutrient rates and drought stress throughout the experimental period. Arrow at D3 indicates the end of the VPS and start of RPS. (Vertical bars represent the LSD $(0.05)$ value indicates the difference among the water stress under same level of nutrient rates and among the nutrient rates under same level of water stress.)

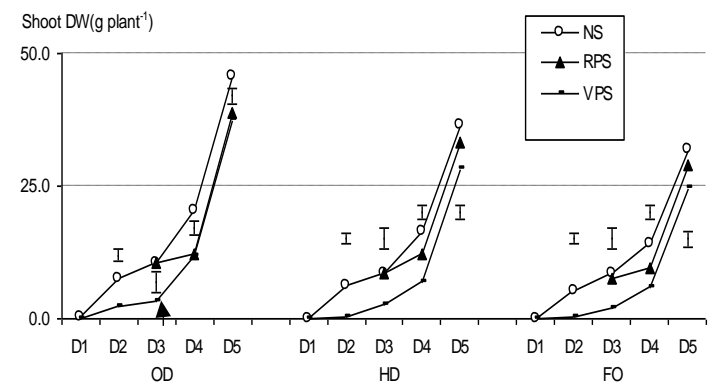

Fig. 3. Shoot dry weight as affected by nutrient rates and drought stress throughout the experimental period. Arrow at D3 indicates the end of the VPS and start of RPS. (Vertical bars represent the LSD (0.05) value indicates the difference among the water stress under same level of nutrient rates and among the nutrient rates under same level of water stress.) 
Grains number and sterility percentage. Regardless of nutrient rates, RPS plants significantly $(\mathrm{P}<0.05)$ produced the lowest number of grains panicle ${ }^{-1}$ followed by VPS plants. The NS plants produced the highest number of grains panicle-1. There was no significant difference between NS and VPS plants except OD. The RPS plants were in stressed condition in reproductive phase. As a result it produced the lowest number of grain panicle-1. This result also supported the findings of Anonymous (1990), BRRI (1991), they reported that water stress decreased filled spikelet number, increased empty spikelet number and decreased grain yield.

Despite moisture stress, the highest number of grains panicle ${ }^{-1}$ was observed in OD followed by HD. The lowest number of grains panicle $^{-1}$ was observed in F0. However, in RPS plants, there was no significant difference between OD and HD indicated that OD plants could not produced significantly more grain under moisture stress perhaps concentration of nutrients in the root zone increased so sharply that affected the distribution of nutrients as well as photosynthates from source to sink. As a result grains panicle ${ }^{-1}$ were not increased even after application of optimum doses (OD) of nutrients reflected in the higher percentage of sterility in OD of RPS plants.

Thousand grains weight. The 1000 grains weight (TGW) was not significantly $(\mathrm{P}>0.05)$ affected by drought stress, nutrient rates and their interaction, as it is a varietal character normally may not be affected by cultural practices (Yoshida, 1981). Moreover, water stress was not applied during grain filling period, hence 1000 grain weight was not affected.

Table 1. Yield and yield components of rice as affected by the interaction effect of drought stress and nutrient rates.

\begin{tabular}{|c|c|c|c|c|c|c|}
\hline & \multicolumn{3}{|c|}{ Panicle no. $\left(\mathrm{m}^{-2}\right)$} & \multicolumn{3}{|c|}{ Grains panicle $^{-1}$} \\
\hline Treatment & NS & VPS & RPS & NS & VPS & RPS \\
\hline F0 & $197 \mathrm{bA}$ & $189 \mathrm{bAB}$ & $183 \mathrm{bB}$ & $83 \mathrm{cA}$ & $79 \mathrm{cA}$ & $65 \mathrm{bB}$ \\
\hline HD & $292 \mathrm{aA}$ & $223 \mathrm{aB}$ & $236 \mathrm{aB}$ & $90 \mathrm{bA}$ & $92 \mathrm{bA}$ & $78 \mathrm{aB}$ \\
\hline OD & \multirow{2}{*}{$301 \mathrm{aA}$} & \multirow{2}{*}{$\begin{array}{c}234 \mathrm{aB} \\
12.4\end{array}$} & \multirow{2}{*}{$241 \mathrm{aB}$} & \multirow{2}{*}{$106 \mathrm{aA}$} & $99 \mathrm{aB}$ & \multirow[t]{2}{*}{$81 \mathrm{aC}$} \\
\hline \multirow[t]{2}{*}{ LSD at $5 \%$} & & & & & 4.3 & \\
\hline & \multicolumn{3}{|c|}{$\%$ sterility } & \multicolumn{3}{|c|}{ 1000-grain weight (g) } \\
\hline Treatment & NS & VPS & RPS & NS & VPS & RPS \\
\hline F0 & $18 \mathrm{aC}$ & $23 \mathrm{aA}$ & $24 \mathrm{bA}$ & 22.19 & 22.02 & 21.76 \\
\hline HD & $16 \mathrm{abC}$ & $21 \mathrm{abB}$ & $26 \mathrm{abA}$ & 22.38 & 22.23 & 22.34 \\
\hline OD & $14 \mathrm{bC}$ & $19 \mathrm{bB}$ & 29 aA & 22.26 & 22.13 & 21.85 \\
\hline \multirow[t]{2}{*}{ LSD at $5 \%$} & & 3.1 & & & ns & \\
\hline & \multicolumn{3}{|c|}{ Grain yield $\left(\mathrm{t} \mathrm{ha}^{-1}\right)$} & \multicolumn{3}{|c|}{ Straw yield $\left(\mathrm{t} \mathrm{ha}^{-1}\right)$} \\
\hline Treatment & NS & VPS & RPS & NS & VPS & RPS \\
\hline FO & $3.14 \mathrm{cA}$ & $2.73 \mathrm{bA}$ & $2.54 \mathrm{bA}$ & $5.30 \mathrm{bA}$ & $4.92 \mathrm{aA}$ & $5.14 \mathrm{bA}$ \\
\hline HD & $5.62 \mathrm{bA}$ & $4.61 \mathrm{aB}$ & $4.30 \mathrm{aB}$ & $6.71 \mathrm{aA}$ & $5.20 \mathrm{aA}$ & $5.32 \mathrm{bA}$ \\
\hline OD & $6.51 \mathrm{aA}$ & $4.50 \mathrm{aB}$ & $4.20 \mathrm{aB}$ & $7.23 \mathrm{aA}$ & $5.10 \mathrm{aC}$ & $6.70 \mathrm{aB}$ \\
\hline LSD at $5 \%$ & & 0.60 & & & 0.93 & \\
\hline
\end{tabular}

In a column, numbers followed by different small letters $(a, b, c)$ differ significantly at the $5 \%$ level by LSD test. In a row, numbers followed by different capital letters (A, B, C) differ significantly at the $5 \%$ level by LSD test. 
Grain yield. Grain yield is a function of many factors like panicles $\mathrm{m}^{-2}$, grains panicle ${ }^{-1}$ and $(\mathrm{TGW})$ was also significantly $(\mathrm{P}<0.05)$ affected by the interaction effect of drought stress and nutrient rates. Regardless of nutrient rates, unstressed plants (NS) produced the highest grain yield (3.14 to $6.51 \mathrm{t}$ ha $^{-1}$ ) followed by VPS ( 2.73 to 4.50 tha $\left.^{-1}\right)$ plants. The RPS plants produced the lowest grain yield (2.54 to $\left.4.20 \mathrm{t} \mathrm{ha}^{-1}\right)$. This result supported the findings of Boonjung and Fukai (1996); Mostajeran and Rahimi-Eichi, (2009). They found that drought stress at vegetative phase of rice had a minor effect on subsequent growth and grain yield. But they observed that water stress at panicle development stage decrease grain yield due to delayed anthesis and the number of spikelets per panicle reduced upto $60 \%$ compared to control and the percentage of filled grains.

There was no significant difference among NS, VPS and RPS plants under F0. In $\mathrm{HD}$ and OD, there was no significant difference between VPS and RPS plant. Irrespective of water stress, OD produced the highest grain yield (4.20 to $\left.6.51 \mathrm{tha}^{-1}\right)$ followed by HD (4.30 to $\left.5.62 \mathrm{t} \mathrm{ha}^{-1}\right)$ and F0 (2.54 to $3.14 \mathrm{t}$ $\left.\mathrm{ha}^{-1}\right)$. There was no significant difference between HD and OD under VPS and RPS plants. Though OD produced the highest grain yield but due to water stress the highest grain yield reduction was observed in OD (22-32\%) followed by HD (12-19\%) and the lowest in FO (4-15\%) (Fig. 4).

Due to water stress the grain yield decreased more in plants grown in higher dose nutrient i.e. OD than HD and F0. This result confirms the findings of Power, 1990; Christianson and Vlek, 1991). They reported that with adequate amounts of soil moisture (humid=350 mm mid-season rainfall), grain yield of cereal response to nutrients is significant, but during severe drought (dry=100 mm mid-season rainfall) mineral application actually reduced yields. This result also supported the findings of Halder and Burrage (2007).
Straw yield. Irrespective of nutrient rates, unstressed plants (NS) produced the highest straw yield (5.30 to $7.23 \mathrm{t} \mathrm{ha}^{-1}$ ) followed by RPS (5.14 to $6.70 \mathrm{t} \mathrm{ha}^{-1}$ ) plants. The VPS plants produced the lowest straw yield (4.92 to 5.20 $\mathrm{t}$ ha $\left.^{-1}\right)$. There was no significant difference among NS, VPS and RPS except OD. Irrespective of water stress, the OD gave the highest straw yield (5.21 to $7.23 \mathrm{t} \mathrm{ha}^{-1}$ ) followed by HD (5.20 to $\left.6.71 \mathrm{t} \mathrm{ha}^{-1}\right)$ and F0 (4.92 to 5.30 $\left.\mathrm{t}^{\mathrm{t}} \mathrm{a}^{-1}\right)$ but there was no significant $(\mathrm{P}>0.05)$ difference between F0 and HD of RPS plants, between HD and OD treatments of NS plants and among F0, HD, OD of VPS plants. In this experiment water stress decreased tiller number and plant height hence decreased straw yield. This is an agreement with the findings of Hossain et al. 2002.

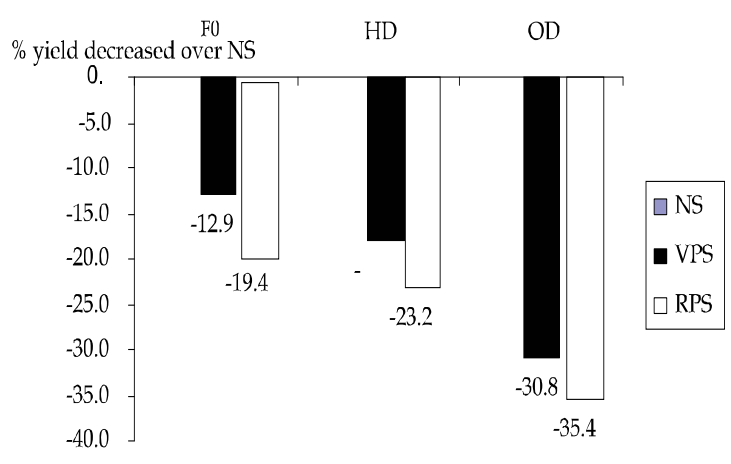

Fig. 4. Percent grain yield reduction in VPS and RPS plants over unstressed (NS) plants.

\section{CONCLUSION}

Water stress decreased growth of the plant due to reduction of plant height and tiller number. When a higher dose of fertilizer was applied in stressed plant, there was a greater percentage of reduction of grain yield than the lower dose of fertilizer applied stressed plant. Therefore, if fertilizer is applied, proper water supply must be ensured, otherwise yield will be reduced drastically. 


\section{REFERENCES}

Anomymous. 1990. Effect of different levels of light and drought stress on individual spikelet filling in rice. PhD thesis. UPLB, College, Laguna, Philippines.

Blum, A, J Mayer, and G Gozlan. 1983. Associations between plant production and some physiological components of drought resistance in wheat. Plant, Cell and Environment. 6: 219-225.

Boonjung, H and S Fukai. 1996. Effects of soil water deficit at different growth stages on rice growth and yield under upland conditions. 2. Phenology, biomass production and yield. Field Crops Research 48 (1):47-55.

BRRI. 1991. Annual report for 1988. Gazipur, Bangladesh. pp. 1-104.

Castilo, E, J Siopongco, R J, Buresh, K T Ingram and S K De Datta. 1987. Effect of nitrogen timing and water deficit on nitrogen dynamics and growth of lowland rice. IRRI Saturday, 7 November 1987. Los Banos, Laguna, Phillippines.

Christianson, C B and, P L G Vlek. 1991. Alleviating soil fertility constraints to food production in West Africa: Efficiency of nitrogen fertilizers applied to food crops. Fertiliser Research. 29:21-33.

Cruz, R. T, J C O'Toole, M Dingkuhn, E M Yambao and M Thangaraj. 1986. Shoot and root response to water dficits in rainfed low land rice. Aust. J. Plant Physiol. 13: 567-575.

Davies, W J, M A, D S Thompson, W Sobeih, L G Rodriguez. 2000. Regulation of leaf and fruit growth in plants growing in drying soil: exploitation of the plants' chemical signalling system and hydraulic architecture to increase the efficiency of water use in agriculture. J of Experimental Botany. 51: 1617-1626.

Halder, K P and S W Burrage. 2003. Drought stress effects on water relations of rice grown in nutrient film technique. Pakistan Journal of Biological Sciences. 6 (5): 441-444.

Halder, K P and S W Burrage. 2004. Effect of drought stress on photosynthesis and leaf gas exchange of rice grown in nutrient film technique. Pakistan Journal of Biological Sciences. 7 (4): 563-565.

Halder, K P and S W Burrage. 2007. Water stress and nutrient solution electrical conductivity (EC) on rice plant III. Yield and yield component. Bangladesh Rice Journal. 12 (1\&2):31-35.

Rikan, H, M Heidary and R Jameiy. 2007. Study on tolerance to salinity and drought of 4 barley cultivar in germination phase. Research and Reconstruction Magazine, 4 (74): 34-142.

Hossain, S T, M S U Bhuiya, M A Islam, M A Kashem and M A Mannan. 2002. Effect of water stress on the performance of yield of fine rice. Bangladesh Journal of Environmental Sciences. 6: 251-257.

Hsiao, T C. 1973. Plant responses to water stress. Annual Review, Plant Physiology. 24: 519-570.
Hsiao, T C. 1982. The soil plant atmosphere continuum in relation to drought resistance in crop with emphasis on rice. International Rice Research Institute, Los Banos, Laguna, Philippines.

IRRI (International Rice Research Institute). 1976. Soil water relations in rice. Annual report for 1975. IRRI research Papers Series, 14. IRRI, Los Banos, Laguna, Philippines. pp 152-154.

Jana, R K and B P Ghildyal. 1972. Effect of varying soil water regimes during the different growth phases on the yield of winter rice. Riso. 21: (1) 93-95.

Keller, M. 2005. Deficit irrigation and vine mineral nutrition. American Journal Enol Vitic. 56: 267-283.

Khush, G. 2005. What it will take to feed 5.0 billion rice consumers in 2030, Plant Molecular Biology, 59, 1-6.

Lee, Jiann Feng, Chen Shih Shiung, J F Lee and S S Chen. 1994. Effects of irrigation level on growth of rice during the vegetative growth stage: grain yields and yield components. Bulletin of Taichung District Agricultural Improvement Station. No. 42, 29-40.

Mengel, K and E A Kirkby. 1987. Principles of plant nutrition. International Potash Institute, Worblanfen Bern, Switzerland. 687p.

Molden, D, T Oweis, P Steduto, P Bindraban, M A Hanjra, J Kijne. 2010. Improving agricultural water productivity: Between optimism and caution. Agricultural Water Management, 97: 528- 535.

Mostajeran, A and V Rahimi-Eichi. 2009. Effects of drought stress on growth and yield of rice (Oryza sativa L.) cultivars and accumulation of proline and soluble sugars in sheath and blades of their different ages leaves. American Eurasian J. Agric. \& Environ. Sci., 5 (2): 264-272.

Murty, K S and G Ramakrishnaya. 1982. Shoot characteristics of rice for drought resistance. In: Drought resistance in crops with emphasis on rice. International Rice Research Institute. Los Banos. Laguna. Philippines. pp 145-152.

Toole, O J C and R T Cruz. 1979. Leaf rooling and transpiration. In: proc. Crop Sci. Soc. Jap. (Special issue), Plant Sci. Lett. Tokyo, Japan. 16: 111-114.

Okada, K, M Kondo, H, Ando and K Kakuda. 2002. Water uptake under water stress at panicle imitation stage in upland rice as affected by previous soil water regimes. Soil Sci Plant Nutr. 48: 151-158.

Penning de Vries, F WT, D M Jansen, H F M Ten Berge and A Bakema. 1989. Simulation of ecophysiological process of growth in several annual crops. Intl. Rice Res. Instt., Philippines, Los Banos/ Pudoc, Wageningen, Philippines., 28-30, April 1987. Univ. Philipp. Los Banos, College, Laguna Philippines. 271p.

Power. 1990. Fertility management and nutrient cycling. In: Singh R.P. et al. (eds.) Advances in Soil Sciences. Dryland agriculture strategies for sustainability. New York. 13:131-147.

Rice is Life. International Year of Rice. 2004 and its Implementation 2005. FAO, Rome; ISBN 92-5-105364-2. 
Sabetfar, S, M Ashouri, E Amiri and S Babazadeh. 2013. Effect of drought stress at different growth stages on yield and yield component of rice. Plant Persian Gulf Crop Protection, 2 (2): 14-18

Sharma, P K, S K De Datta and C A Redulla. 1987. Root growth and yield response of rainfed lowland rice to planting method. Expl. Agric. 23: 305-313.

Slatyer, R O. 1969. Physiological significance of internal water relations in crop yield. In: J. D. Eastin, J. D. (eds) Physiological Aspects of Crop Yield Amer. Soc. Agron., Madison, Wisconsin. pp 53-79

Smith, D L and C Hamel. 1999. Crop yield physiology and processes. Springer, Berlin. pp. 504.

Tuong, T P, E G Castillo, R C Cabangon, A Boling and U Singh. 2002. The drought response of lowland rice to crop establishment practices and N-fertilizer sources. Field Crops Res. 74, 243-257.
Viets, F G, Jr. 1972. Water deficits and nutrient availability. In: Kozlowski, T T (ed.) Water deficits and plant growth. Academic Press, New York. pp. 217-236.

Waraich, E A, R Ahmad, Saifullah, M Y Ashraf and Eh Saifullah. 2011. Role of mineral nutrition in alleviation of drought stress in plants. Australian Journal of Crop Science, 5 : 764-777.

Yang, C M, H W Min, C W Yang and W M Hsiang. 1994. Growth and yield of rice as affected by soil water deficits. Chinese Journal of Agrometeorology. 1: (4) 143-150.

Yoshida, S. 1981. Fundamentals of rice crop science. International Rice Research Institute, Los Banos, Laguna, and Philippines. 267p.

Zumber, M A, A K M M B Chowdhury, M Z Islam, T Ahmad and M A Hasan. 2007. Effects of water stress on growth and yield attribute Aman rice genotype. International Journal of Sustainable Plant Production, 2(6): 25-30. 